\title{
ABBREVIATIONS USED IN REFERENCES TO SCHILLEBEECKX'S WORKS
}

\author{
Christ Christ: The Experience of Jesus As Lord \\ Church Church: The Human Story of God \\ Interim Report Interim Report on the Books "Jesus" and "Christ" \\ Jesus \\ Jesus: An Experiment in Christology \\ Ministry \\ Ministry: Leadership in the Community of Jesus Christ \\ Testament \\ Theologisch testament
}


